Review: Evaporation Conditions at Skokie Marsh, Illinois

Source: Journal of Ecology, Vol. 1, No. 3 (Sep., 1913), pp. 195-196

Published by: British Ecological Society

Stable URL: http://www.jstor.org/stable/2255343

Accessed: 23-06-2016 23:13 UTC

Your use of the JSTOR archive indicates your acceptance of the Terms \& Conditions of Use, available at

http://about.jstor.org/terms

JSTOR is a not-for-profit service that helps scholars, researchers, and students discover, use, and build upon a wide range of content in a trusted digital archive. We use information technology and tools to increase productivity and facilitate new forms of scholarship. For more information about JSTOR, please contact support@jstor.org.

Wiley, British Ecological Society are collaborating with JSTOR to digitize, preserve and extend access to Journal of Ecology 
there is no sharp.line of division between the two; here both slopes are entirely barren of treeson the basis of the wind theory this might be explained on the ground that here the wind has a clean sweep across both slopes.

The fact that the soil on those parts of Cattle Point and South Hill where the forest has failed to grow is gravelly suggested that the difference in soil on the two slopes may be the chief cause of the difference in forest distribution, and the author has investigated carefully the character of the soil on the barren and forested portions of the four elevations. In all four cases the soil on the barren portion is black and powdery, containing a good deal of gravel, while the forested portion is everywhere covered with two feet or more of yellow clay containing occasional irregular fragments of rock. The clay layer is largely free from gravel, and at the surface there are a few inches of forest humus; below the clay the character of the soil is much as it is at the surface on the barren portion of the elevation. In one place on the Cattle Point elevation a portion of the northern slope is without trees, and this portion shows the same black gravelly soil as that of the barren southern slopes; the low ridge above referred to was found to have gravelly soil on both slopes.

On South Hill, Spieden Island, and Sentinel Island the trees at the summit show practically no distorting effect of the wind; whatever wind effect takes place is confined to the very tops of the trees and is so slight that it can be detected only on careful scrutiny of individual trees. The bending of trees, apparently as a result of wind, is common throughout San Juan Island, and the bending of the tops of occasional trees on the three elevations referred to seems to be no greater than in other places where the forest flourishes in spite of the influence of wind on the tree tops. On Spieden Island occasional trees are found on the southern slope and even these are practically free from wind effects; many of the trees on the southern slope are Quercus garryana, a very few are Pseudotsuga taxifolia, and while a good many Quercus trees are found on the summit of the ridge, only occasional ones are found in the forest on the northern slope and these only near the summit. The conditions here of a transition from a yellow clay soil producing a fir forest to a gravelly soil producing practically no trees is strikingly similar to the conditions found near Tacoma, Washington, where the forest borders the open gravelly prairie; the fringe of oaks between the forested area and the open prairie occurs in both cases.

From the author's observations it is seen that of the four cases of barren southern slopes and forested northern slopes described, only one shows any conspicuous evidence of the effect of wind, and it seems difficult to accept as the single common cause an influence that shows any considerable effect in only one case. Among subjects worthy of investigation he mentions the extent to which the relative water-holding capacity of the two soils is responsible for the forested condition on the one and the barren condition of the other, as well as the question of their relative fitness for the growth of mycorhiza and micro-organisms which may possibly be determining factors in this forest distribution; and he concludes that while several factors are probably concerned in the question of forest distribution in cases like this, large consideration will have to be given to edaphic factors.

\section{EVAPORATION CONDITIONS AT SKOKIE MARSH, ILLINOIS}

Sherff, E. E. “Evaporation conditions at Skokie Marsh.” Plant World, 16, 1913, pp. 154-160.

The general ecological conditions at Skokie Marsh have been described by the author (see notice in this Journal, 1, pp. 112-113). As shown by Livingston in his well-known studies of transpiration, in a general way the measure of transpiration in plants is fairly indicative of their respective environmental conditions; the transpiration rate for most plants being roughly proportional to the rate of evaporation of water from a partially open receptacle, he introduced the porous-cup atmometer for measuring the evaporation rate of water. The author set four atmometers at different stations (A) near the edge of the stream, (B) in the outer part of the reed swamp, (C) in the outer part of the swamp meadow, (D) in a stretch of forest beyond the swamp meadow. No. 1 was in the centre of a dense growth of Typha angustifolia-as summer advanced, plants of Teucrium occidentale and Scutellaria galericulata grew up in the shelter of the Typha; 
No. 2 was surrounded by Iris, Sium, and a few Typha plants; No. 3 was in a dense growth of Calamagrostis; No. 4 in a small area of pastured forest composed chiefly of Quercus bicolor and Fraxinus americana.

The records show that the periods of maximum and minimum evaporation were fairly harmonious at the four stations, also that evaporation was usually lowest in the centre of the reed swamp where hydrophytism is greatest, somewhat higher in the swamp meadow, still higher in the outer part of the reed swamp, and highest of all in the Quercus-Fraxinus forest. The average daily evaporation amounts for the entire period of 147 days were:-A, 3 c.c.; B, 4.5 c.c ; C, 4.27 c.c.; $\mathrm{D}, 7 \cdot 91$ c.c. In general terms, the evaporation rates were inversely proportional to the hydrophytism of the station. This is due chiefly to the larger amount of moisture in the air where the station is hydrophytic; and again the greater amount of atmospheric moisture was due, in many places, not merely to the greater sources of supply (soil moisture or surface water) but to the more difficult means of escape (because of the tall rank vegetation evoked by hydrophytic conditions). The average rate in the outer part of the reed swamp slightly exceeded that in the swamp meadow; this may be explained readily by the fact that in the swamp meadow the vegetation remained more dense and compact in late summer than in the outer part of the reed swamp, thus retarding evaporation.

Transeau (Bot. Gaz., 45, 1908) obtained in a mesophytic forest on Long Island an average daily evaporation rate of $8.5 \mathrm{~cm}$., based on readings taken during a period of less than one month; Fuller (Bot. Gaz., 52, 1911) obtained for mesophytic forest the average daily rate of $8.1 \mathrm{~cm}$., based on readings extending over 155 days. Though the dates available do not justify final comparisons, they indicate that evaporation is strictly less rapid in the swamp Quercus-Fraxinus forest than in climax mesophytic forest; and if this be confirmed by further study, it will coincide very exactly with the fact that in the normal development of mesophytic forest from hydrophytic formations such species as Quercus bicolor, Fraxinus americana, etc., are antecedent to trees of the climax mesophytic type (Fagus grandifolia, Acer saccharum, etc.).

In the autumn of 1911 the author made a study of evaporation at different levels above the soil surface; readings were taken from September 3 to October 22 with four atmometers arranged at different heights in a dense growth of Phragmites, and with four atmometers added to the one already at station no. 1 among Typha. Among Phragmites the average daily evaporation for the seven weeks at the soil surface was 2.5 c.c.; at $25 \mathrm{~cm} ., 4$ c.c.; at $107 \mathrm{~cm} ., 5 \cdot 3 \mathrm{c.c}$; at $198 \mathrm{~cm}$. (in the uppermost atmospheric stratum among the Phragmites plants), $7 \cdot 5$ c.c. Among Typha the average daily evaporation at the soil surface was 0.64 c.c.; at $25 \mathrm{~cm} ., 1.5$ c.c.; at $107 \mathrm{~cm}$, 2.7 c.c.; at $175 \mathrm{~cm}$. (in the uppermost stratum), $6 \cdot 4$ c.c. These differences in rate among the Typha were strongly accentuated because the readings were taken in autumn when many of the Typha leaves had begun to wither and bend over, thus giving greater exposure in the upper and greater shelter in the lower strata; also, numerous plants of Scutellaria, Teucrium, Polygonum, etc., absent among Phragmites, were present among Typha and acted as a further check to evaporation in the lower strata in which to a large extent they vegetated.

The author's results confirm very emphatically those of Yapp (Ann. Bot., 23, 1909), who found that during a total of 15 days the evaporation rate just above (not, as at Skokie Marsh, in the upper strata of) tall sedge vegetation was over 1500 per cent. as great as at $12.5 \mathrm{~cm}$. above the soil surface. They also agree with the results of Dachnowski (Bot. Gaz., 52, 1911), who obtained during about 5 days, at a height of $150 \mathrm{~cm}$. in an American bog, an evaporation rate 200 per cent. as great as at a height of $7 \cdot 5 \mathrm{~cm}$. The author therefore concludes with Yapp that plants may grow in close proximity to each other and yet, if vegetating in different strata above the soil surface, be subject to widely different growth conditions. For instance, Riccia natans and Typha latifolia may be found together in great quantity, but they vegetate mostly in different atmospheric strata and live under evaporation conditions much more different than do Teucrium occidentale (of the reed swamp) and Aster salicifolius (of the swamp Quercus-Fraxinus forest), plants of similar height and growth form. 